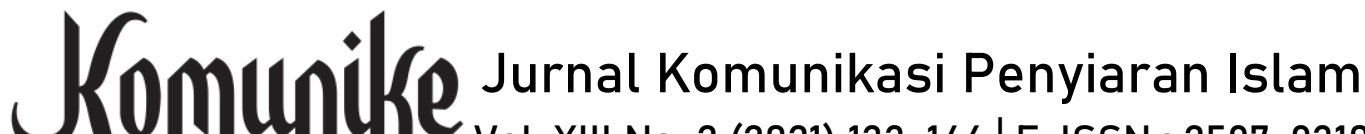 Vol. XIII No. 2 (2021) 133-146 | E-ISSN : 2597-9310
}

Submission : 15 - 12 - 2021 |Revisions : 30 - 12 - 2021|DOI: 10.20414/jurkom.v13i2.4419

\section{PERUBAHAN SOSIAL DAN TRADISI PHUBBING: TELAAH PERILAKU KOMUNIKASI MASYARAKAT DIGITAL DI KELURAHAN SURYAWANGI, LOMBOK TIMUR}

\author{
Hamzani Khairul Ihsan(1), Daeng Sani Ferdiansyah, Muhammad Yani \\ Institut Agama Islam Hamzanwadi NW Pancor \\ ${ }^{(1)}$ sanihsan94@gmail.com
}

\begin{abstract}
The presence of new media such as gadgets became a staple of digital society, namely the generation that grew up in the 20th century. One of the dmpak produced by digitalization is the tradition of phubbing, which is the condition of society that prioritizes gadgets over friends around. Phubbing occurs because users are unable to utilize technology wisely as a result of feeling bored and conversations that are no longer interesting. The research method used is qualitative with a type of phenomenology. The results showed that phubbing one of the behaviors that are contrary to social norms that exist in public life one of them is mutual respect between each other and communication. The attitude of dependence on gadgets makes the digital community in Suryawangi become an introverted human being to his own world.
\end{abstract}

Keywords: Social Change, Phubbing, Communication Behavior, Digital Society

\begin{abstract}
Abstrak
Kehadiran media baru seperti gadget menjadi kebutuhan pokok masyarakat digital yaitu generasi yang tumbuh di abad 20. Salah satu dmpak yang dihasilkan oleh digitalisasi tersebut adalah tradisi phubbing yaitu kondisi masyarakat yang lebih memprioritaskan gadget dari pada teman sekitar. Phubbing terjadi karena pengguna tidak mampu memanfaatkan teknologi dengan bijak akibat dari perasaan yang bosan dan pembicaraan yang tidak lagi menarik. Metode penelitian yang digunakan adalah kualitatif dengan jenis fenomenologi. Hasil penelitian menunjukkan bahwa phubbing salah satu perilaku yang bertentangan dengan norma-norma sosial yang ada dalam kehidupan bermasyarakat salah satunya adalah sikap saling menghargai antar sesama lawan komunikasi. Sikap ketergantungan terhadap gadget menjadikan masyarakat digital di Suryawangi menjadi manusia introvert terhadap dunianya sendiri.
\end{abstract}

Kata Kunci: Perubahan Sosial, Phubbing, Perilaku Komunikasi, Masyarakat Digital

Lisensi

Creative Commons Attribution-NonCommercial 4.0 International License 


\section{A. PENDAHULUAN}

Perkembangan teknologi digital tidak dapat dipungkiri bahwa saat ini telah mampu mempengaruhi setiap bidang dalam kehidupan manusia, terutama di bidang teknologi dan informasi. ${ }^{1}$ Jika pada zaman dahulu orang berkomunikasi dengan mengharuskan diri untuk bertatap muka secara langsung, maka pada era digital ini sebaliknya, seseorang tidak lagi harus bertemu dengan menyampaikan pesan maupun informasi.

Era digital merupakan istilah yang familiar yang digunakan pada kemunculan digital, jaringan internet khususnya teknologi informasi. Media baru Era Digital sering kali digunakan untuk menggambarkan teknologi digital. Media ini memiliki karakteristik yang dapat dimanipulasi, bersifat jaringan atau internet, selain internet seperti media cetak, telivisi, majalah, koran dan lainlain bukanlah termasuk dalam kategori media baru. Media massa Beralih ke media baru atau internet karena ada pergeseran budaya dalam sebuah penyampaian informasi. kemampuan media informasi diera digital ini lebih memudahkan masyuarakat dalam

\footnotetext{
${ }^{1}$ Ivany Racmi "Hubungan Kesantunan Pergaulan dan perilaku phubbing pada mahasiswa UIR" (Skripsi, Universitas Islam Riau, 2019), hlm. 1
}

menerima informasi lebih cepat dalam hal ini media handphone banyak diminati oleh kebanyakan orang karena perkembangannya yang terus menerus mengikuti perkembangan zaman.

Era digital adalah masa dimana semua manusia dapat saling berkomunikasi sedemikian dekat walaupun saling berjauhan.Kita dapat dengan cepat mengetahui informasi tertentu bahkan real time.Salah satu perkembangan di era digital saat ini yaitu teknologi media kemonikasi digital. Komunikasi Digital adalah cara komunikasi keluar yang memanfaatkan teknologi digital untuk menyampaikan pesan: email, video, pesan teks, iklan online, pencarian berbayar, siaran pers yang dioptimalkan, podcast, vodcast, dll.

Penggunaan alat komunikasi digital seperti handphone merupakan sesuatu yang lumrah untuk dimiliki mulai dari kalangan anak-anak hingga orang dewasa. Hal tersebut merupakan sesuatu yang positif jika tepat pada penggunaannya, akan tetapi jika penggunaannya tidak terkontrol oleh si pengguna maka akan memiliki dampak negatif dan memberikan perilaku yang negatif kepada pengguna handphone. Seperti terlalu banyak menggunakan handphone sampai lupa kepada orang 
disekitar sehingga mendatangkan keresahan bagi masyarakat lain.

Tantangan pada Era Digital telah pula masuk ke dalam berbagai bidang seperti politik, ekonomi, sosial budaya, pertahanan, keamanan, dan teknologi informasi itu sendiri. Era digital terlahir dengan kemunculan digital, jaringan internet khususnya teknologi informasi komputer. Media baru era digital memiliki karakteristik yang dapat dimanipulasi. Kemampuan media era digital ini lebih memudahkan masyarakat dalam menerima informasi lebih cepat. Dengan media internet membuat media massa berbondongbondong pindah haluan. ${ }^{2}$ Semakin canggihnya teknologi digital masa kini membuat perubahan besar terhadap dunia, lahirnya berbagai macam teknologi digital yang semakin maju telah banyak bermunculan. Berbagai kalangan telah dimudahkan dalam mengakses suatu informasi melalui banyak cara, serta dapat menikmati fasilitas dari teknologi digital dengan bebas dan terkendali.

Handphone adalah sebagai salah satu alat komunikasi informasi di era digital saat ini, karenanya sangat

\footnotetext{
${ }^{2}$ Rosalinda Palit,dkk,"Perilaku Masyarakat Era Digital", Jurnal Administrasi Publik, Manado, Vol.1, No.99, (2021), hlm.73.
}

mempermudah masayrakat untuk mendapatkan informasi seperti berita yang sedang terjadi pada saat ini, bahkan berita yang telah terjadi pada masa lampau. Kehadiran media handphone menjadi kebutuhan pokok bagi mayarakat digital. Bagi mereka kemudahan yang ditawarkan jauh lebih banyak dari pada menyadari atas kemungkinan dampak negatif yang ditimbulkan seperti penggunaan yang terlalu berlebihan sehingga mengabaikan lingkunggan sekitar (phubbing).

Phubbing adalah istilah dalam bahasa inggris yang menggambarkan perilaku seseorang yang terlalu sibuk dan berlebihan dalam penggunaan handphonenya ketika berhadapan dengan orang lain.

Phubbing berasal dari kata "phone" dan "snubbing", yang menggambarkan tindakan menghina seseorang dalam lingkungan sosial dengan memperhatikan ponsel, bukan berbicara dengan orang tersebut secara langsung. Dalam interaksi sosial, "phubber" dapat didefinisikan sebagai seseorang yang memulai Phubbing, dan "phubbee" dapat didefinisikan sebagai orang yang penerima perilaku Phubbing. ${ }^{3}$

\footnotetext{
${ }^{3}$ Varoth Chotpitayasunondh, Karen M. Douglas. (2017). The effects of "phubbing" on social
} 
Phubbing terjadi karena pengguna tidak mampu memanfaatkan teknologi dengan bijak (berlebihan terhadap penggunaan gawai), dapat diduga karena seseorang sedang merasa bosan dan kurang berminat dengan pembicaraan yang dilakukan oleh lawan bicara. Perilaku phubbing yang dilakukan dapat diduga karena lemahnya kontrol diri. Kontrol diri merupakan aspek penting yang perlu diperhatikan di dalam perilaku phubbing. ${ }^{4}$

Dalam hal ini sering kali pemerintah Kelurahan Suryawangi mengharapkan dan menghimbau dalam setiap pertemuan agar masyarakat mampu memanfaatkan teknologi dengan baik. Pada era digital ini masyarakat lebih dituntut agar lebih kritis kepada persoalan teknologi agar tidak cepat tergilas oleh perubahan dan perkembangan zaman.

Dalam teori ketergantungan (Depedency Theory) menurut Melvin Defluer dan Sandra Ball Roceach, adalah teori tentang komunikasi massa yang menyatakan bahwa semakin seseorang tergantung pada suatu media untuk memenuhi kebutuhannya,

interaction. Wiley: Journal Applied for Social Psychology, Vol-1, No 33

4 Kurnia, Shirley, dkk. (2020) "Kontrol Diri Dan Perilaku Phubbing Pada Remaja Di Jakarta”. Media Ilmiah Psikologi,Vol. 18 No. 1, hlm. 60 . maka media tersebut menjadi semakin penting untuk orang itu. ${ }^{5}$ Kebutuhan masyarakat akan alat komunikasi sudah menjadi barang yang lumrah karena memenuhi kebutuhan masyarakat akan informasi yang datang dari dunia luar.

Masyarakat suryawangi merupakan masyarakat yang memiliki kemampuan dalam menggunakan teknologi dimulai dari anak kecil sampai kepada orang dewasa. Setiap orang atau setiap individu bisa dan mampu menggunakan teknologi yang telah tersedia di era digital saat ini, dengan cara memperhatikan orang lain menggunakan alat teknologi di era digital ini dan mampu menerapkannya dalam aktivitas sehari-sehari.

Penggunaan handphone yang terlalu berlebihan seringkali menjadi sorotan kebanyakan orang, karena dalam penggunaannya tidak dapat mengontrol diri sehingga lupa bahwa ada lingkungan sekitar yang harus diperhatikan, ada teman dekat yang harus dilawan berbicara, ada keluarga yang harus diajak berinteraksi.

Fenomena phubbing saat ini sudah menjadi penyakit pada masyarakat. Seakan-akan tidak bisa dihilangkan

5 Mohd. Rafiq, "Dependency Thory(Melvin L. DeFleur dan Sandra Ball Rokeach)" dalam Jurnal HikmahVol. VI, No. 01 (Sumatera Utara: 2012), hlm. 6. 
karena handphone akan selalu diisi oleh penggunanya. Tentu saja hal ini dapat mengganggu harmonisasi dalam bermasyarakat dan dapat mengubah kebiasaan dan perilaku masyarakat.

Kegiatan kumpul-kumpul yang seharusnya dinilai baik karena dapat menguatkan tali silaturrahim sekaligus berbagai pengalaman dan berinteraksi secara langsung dirusak oleh kehadiran phubbing.

Sering kali dalam kegiatankegiatan berkumpul masyarakat handphone dilepas bahkan dikumpulkan sebagai salah satu inisiatif agar komunikasi bisa berjalan dengan baik. Ternyata hal tersebut tidak juga bertahan lama, karena banyak notifikasi yang masuk dalam handphone itu sendiri, sehingga menyebabkan putusnya pembicaraan atau obrolan yang sedang berjalan.

Masyarakat yang tidak pandai dalam menggunakan teknologi sering kali dicap dengan istilah Gaptek(gagap teknologi). Padahal tidak semua orang yang pandai dalam menggunakan teknologi itu dicap sebagai orang yang bijak berteknologi. Maka, sebagai pengguna teknologi yang baik seperti handphone haruslah mampu melakukan kontrol diri terhadap penggunaannya sehingga menghasilkan cerminan budaya yang baik.

\section{B. LITERATURE REVIEW}

Berdasarkan hasil penelusuran terhadap penelitian-penelitian terdahulu, peneliti menemukan beberapa penelitian terdahulu yang relevan dengan penelitian ini. Meskipun terdapat keterkaitan pembahasan, penelitian ini masih sangat berbeda dengan penelitian terdahulu. Adapun beberapa penelitian terdahulu tersebut yaitu:

Pertama. Penelitian Muhammad Ali Ridho, dalam skripsi yang berjudul "Interaksi Sosial Pelaku Phubbing". Dalam skripsi ini menunjukkan interaksi sosial yang melakukan phubbing cenderung rawan terjadi saat mereka mengimitasi, mengidentifikasi peilaku dari orang-orang disekitarnya serta mengikis sifat simpati pada lawan bicara yang mengajak kita bicara selain itu juga timbul kontak sosial negatif yaitu kontak sosial atau komunikasi yang mengalami pertentangan, hilangnya sementara interaksi yang berlangsung bahkan kemarahan dari lawan bicara yang diabaikan.

Kedua. Penelitian Rafinitia Aditia, dalam jurnal yang berjudul "Fenomena

\footnotetext{
${ }^{6}$ Muhammad Ali Ridho, "Interaksi Sosial Pelaku Phubbing" (Skripsi-UIN Sunan Ampel, Surabaya. 2019), hlm. Ix.
}

Hamzani Khairul Ihsan, dkk 137 
Phuubbing: Suatu Degradasi Relasi Sosial Sebagai Dampak Media Sosial". ${ }^{7}$

Dalam Jurnal ini telah menunjukkan bahwa perilaku phubbing mampu mengancam terganggunya hubungan komunikasi yang sedang berlangsung, sehingga menyebabkan degradasi sosial. Degradasi sosial yang terjadi ialah karena dampak dari keacuhan pelaku phubbing terhadap lingkungannya karena terlalu sibuk menggunakan smartphone, terlebih dalam penggunaan media sosial. Oleh karena itu penggunaan media sosial perlu dibatasi dan dikontrol dengan baik agar fenomena phubbing dapat segera teratasi dan degradasi relasi sosial tidak terjadi. Dalam Jurnal ini peneliti telah memperhatikan bahwa perlu adanya pengkajian kembali, sebab Phubbing bukan hanya pada proses komunikasi tetapi juga pada etika komunikasi. Karena komunikasi merupakan hal yang paling krusial dalam kehidupan manusia, maka penting dalam proses terjadinya komunikasi diperlukan etika komunikasi agar proses komunikasi mampu berjalan dengan baik.

\footnotetext{
7 Rafinitia Aditia, "Fenomena Phubbing: Suatu Degradasi Relasi Sosial Sebagai Dampak Media Sosial", KELUWIH: Jurnal Sosial dan Humaniora, Vol. 2 (01), No. 8-14 (April, 2021),hlm. 8
}

Ketiga. Penelitian Raden Gita Ekapravita dan Iqbal Prabawa Wiguna, dalam jurnal yang berjudul "Dampak Phubbing Pada Interaksi Sosial". ${ }^{8}$ Dalam jurnal ini telah dicermati bahwa Smartphone menjadikan masyarakat dan generasi muda mengalami perubahan pola perilaku terhadap orang-orang disekitarnya. Sehingga muncul fenomena dengan istilah baru yaitu phubbing, Perilaku tersebut telah menjadi normatif dalam komunikasi sehari -hari. Elemen penting dari fenomena tersebut adalah adanya pengucilan sosial di mana seseorang diabaikan oleh orang lain sementara mereka tetap berada di hadapan orang tersebut, mereka menjadi tertutup dalam interaksi sosial.

Keempat. Penelitian Ivany Rachmi, dalam skripsi yang berjudul "Hubungan Kesantunan Pergaulan Dengan Perilaku Phubbing Pada Mahasiswa Universitas Islam Riau (UIR)".9 Dalam Skripsi menunjukkan bahwa smarthone telah menyebabkan timbulkan beberapa perubahan pola perilaku masyarakat

\footnotetext{
8 Raden Gita Ekapravita dan Iqbal Prabawa Wiguna, "Dampak Phubbing Pada Interaksi Sosial", e-Proceeding of Art \& Design, Vol. 6, No. 3 (Desember 2019), hlm. 4565

9 Ivany Rachmi, "Hubungan Kesantunan Pergaulan dengan Perilaku Phubbing pada Mahasiswa Universitas Islam Riau(UIR)", (Skripsi-Universitas Islam Riau, Pekanbaru. 2019), hlm. ii
} 
khususnya pada kaum muda. Individu memiliki dunianya sendiri, bahkan interaksi individu lebih banyak dengan smartphone dibandingkan dengan orang sekitarnya secara langsung.

\section{METODE PENELITIAN}

Mencakup penjelasan tentang metode yang digunakan dalam melakukan penelitian. Adapun substansi dalam metode penelitian ini dapat berupa pendekatan penelitian, jenis penelitian, dan ruang lingkup penelitian.

Penelitian ini dilaksanakan di Kelurahan Suryawangi Kecamatan Labuhan Haji Kabupaten Lombok Timur. Adapun pertimbangan penelitian tersebut dilaksanakan di lokasi ini dengan pertimbangan bahwa didaerah ini mempunyai terpaan teknologi smartphone dikalangan masyarakat

Teknik penentuan informan dalam penelitian ini menggunakan teknik purposive, dengan memilih secara sengaja dan sesuai dengan tujuan penelitian. Pertimbangan utamanya bahwa informasi dibutuhkan, informan dapat memberikan gambaran informasi yang berkaitan dengan permasalahan dan tujuan dalam penelitian ini. Subyek dalam penelitian ini adalah beberapa anggota masyarakat yang bertempat tinggal di lokasi penelitian dan aktif menggunakan smartphone sebagai alat untuk berinteraksi.

Sumber data dalam penelitian ini adalah data primer yang diperoleh dengan melakukan wawancara mendalam kepada para informan yang bersedia, dengan menggunakan pedoman wawancara. Sumber data yang lain adalah data sekunder merupakan data pendukung yang berguna sebagai penunjang dan pelengkap data primer, diperoleh dari beberapa literatur berupa buka-buku, dokumentasi dan sebagainya yang berhubungan dengan objek penelitian.

Teknik pengumpulan data melalui Observasi, yaitu dengan melakukan pengamatan langsung sehingga memungkinkan peneliti melihat dan mengamati kemudian mencatat perilaku dan kejadian, teknik ini digunakan untuk memperoleh data tentang dampak phubbing terhadap keharmonisan bermasyarakat. Teknik selanjutnya yang digunakan dalam penelitian ini adalah melakukan wawancara mendalam untuk mengumpulkan data kualitatif sampai menemukan kesimpulan, dengan menjelaskan fenomena sosial yang terjadi dibalik penggunaan handphone atau smartphone dalam kehidupan bermasyarakat. 
Teknik analisis informasi/data menggunakan analisis interaktif model Miles dan Huberman. Teknik ini menggunakan empat komponen analisis, diawali dengan melakukan pengumpulan data disertai pembuatan catatan lapangan, reduksi data dengan melakukan pengelompokan data sesuai kebutuhan analisis dan pembahasan, selanjutnya melakukan penyajian data, dan terakhir melakukan penarikan kesimpulan.

\section{HASIL DAN PEMBAHASAN}

Dalam era globalisasi ini teknologi semakin maju, tidak dapat dipungkiri bahwa kehadiran handphone sebagai alat komunikasi semakin dibutuhkan dalam kehidupan sehari-hari. Kesempatan ini juga begitu dimanfatkan oleh vendor smartphone yang menjamur dan sudah menjadi trend dimasyarakat, terlebih lagi dengan kemajuan dan perkembangan media sosial yang semakin pesat.

Penggunaan teknologi handphone diera digital ini sudah menjadi kebutuhan yang mutlak, karena bisa melakukan komunikasi dengan orang yang jauh dan tidak harus untuk bertatap muka secara langsung. Penggunaan handphone selain sebagai alat komunikasi juga sebagai hiburan bagi masyarakat terlebih bagi masyarakat yang sudah lanjut usia.

Di era digital ini semua kalangan bisa menikmati dan menggunakan teknologi handphone tidak terkecuali juga untuk orang yang mengalami cacat. Dengan bantuan orang-orang di sekitar seorang yang cacat masih bisa menikmati teknologi gadget di era digital ini. namun, dalam hal penggunaannya juga harus memilik batasan-batasan tertentu agar tidak terjadi penggunaan yang berlebihan yang mengakibatkan perubahan perilaku kepada masyarakat.

Teknologi komunikasi memiliki dampak homogenitas penhgetahuan dan rasa keduniaan(worldness) yang merupakan ruh globalisasi. Sekarang ini, hampir setiap orang menyadari bahwa mereka tinggal di dunia yang sama, hampir setiap orang menyadari bahwa teknologi berfungsi sebagi sebagai jendela dunia. Dunia kini telah menjadi sebuah kampung dunia dimana setiap orang dapat saling mengenal melalui teknologi komunikasi. ${ }^{10}$ Dalam penggunaan teknologi komunikasi seperti handphone tentu harus dipahami dengan baik cara penggunaan agar tidak menimbulkan dampak negatif, salah

10 Teguh Ratmanto, "Determinisme Teknologi dalam Komunikasi dan Informasi", Jurnal Komunikasi, Vol.6, No. 1 (Juni, 2005), hlm.. 44 
satunya yang akan ditimbulkan adalah mengabaikan lawan bicara ketika sedang melakukan obrolan, bukan hanya itu saja bahkan mampu mengabaikan lingkungan sekitar. ${ }^{11}$

Penggunaan handphone sebagai alat komunikasi sudah menjadi kebutuhan karena disamping sebagai alat komunikasi juga sudah mencakup hampir seluruh yang dibutuhkan masyarakat seperti mengrjakan tugas kuliah bagi mahasiswa, pekerjaan kantor bagi para karyawan, mendengarkan ceramah-ceramah bahkan tidak sedikit dari masyarakat yng memanfaat handphone ini juga sebagai alat untuk mendapatkan penghasilan tambahan seperti melakukan berbelanja melalui aplikasi Online.

Terlebih pada era digital kali ini masyarakat lebih dekat dengan handphone genggamnya karena berbagai media sosial seperti Whattsapp, Twitter, Facebook sudah mengambil perannya agar lebih dekat kepada masyarakat dengan menyajikannya dalm bentuk aplikasi yang terintegrasi agar lebih mudah diakses oleh masyarakat.

\section{Menurut Arminen yang dikutip Hendrastomo menyatakan bahwa penggunaan ponsel akan merubah cara}

11 Muliadi, Wawancara, Suryawangi, (14 September 2021). kita berinteraksi berkomunikasi dengan individu lain dengan lebih bebas. Akan tercipta kebebasan yang tanpa batas ruang dan waktu yang memungkinkan individu berkomunikasi satu hari penuh. ${ }^{12}$

Walaupun fungsi handphone mampu meningkatkan komunikasi antar individu, tetapi disisi lain akan memunculkan dampak negatif, mulai dari terkikisnya etika berkomunikasi lewat handphone sampai kepada komunikasi yang tidak kenal waktu sehingga secara tidak sadar mampu menghabiskan waktu yang secara sia-sia dalam bahasa asing dikenal dengan istilah phubbing.

Phubbing menggambarkan tindakan seseorang dalam lingkungan sosialnya fokus terhadap handphonenya sendiri, bukan berbicara secara langsung dengan orang yang ada disekitarnya. Dalam istilah komunikasi Phubber didefinisikan sebagai seeorang yang memulai phubbing dan phubbee dapat didefinisikan sebagai orang yang menerima phubbing. ${ }^{13}$ Sering kali dalam proses komunikasi, phubbing ini sudah

\footnotetext{
12 Abdul Sakban, "Perubahan Sosial Terhadap Pengguna Handphone Di Kalangan Remaja Kota Mataram", dalam Jurnal CIVICUS, Vol. 4, No, 2, (September, 2016), hlm. 73.

13 Varoth Chotpitayasunondh, dkk.,'The Effect of "Phubbing" on social interaction", Wiley: Journal Applied for Social Psychology, Vol. 1, No, 33. (2017), hlm. 135.
} 
menjadi suatu tradisi atau kebiasaan dalam masyarakat karena merupakan bentuk perbuatan yang sering kali di ulang-ulang dengan hal sama.

Ditengah perkembangan zaman saat ini sangat berpengaruh kuat kepada perubahan perilaku masyarakat. Salah satunya ketika internet sudah menjadi konsumsi sehari-hari masyarakat, sehingga tidak memiliki waktu berkomunikasi dengan lingkungan sekitar secara nyata. ${ }^{14}$

Mereka akan cenderung lebih anti sosial dengan orang lain jika hanya fokus kepada medianya sendiri dan hanya berinteraksi melalui handphone dari pada harus keluar rumah untuk berinteraksi secara langsung dengan sesamanya. Menurut Karadagg beberapa faktor yang mempengaruhi terjadinya perilaku phubbing diantaranya yaitu, kecanduan smartphone, kecanduan internet, kecanduan Sosial Media, dan kecanduan game. ${ }^{15}$

Beberapa faktor tersebut tentu menjadi penyebab terjadinya perilaku phubbing terlebih bagi anak muda, bahkan bukan hanya kalangan muda saja. Dimulai dari golongan anak kecil

14 Muliadi, Wawancara, Suryawangi (13 September 2021

15 Ivany Racmi "Hubungan Kesantunan Pergaulan dan perilaku phubbing pada mahasiswa UIR" (Skripsi, Universitas Islam Riau, 2019), hlm. 13 sampai kepada orang dewasa kecanduan dalam bermain game salah satu game yang sering dimainkan seperti Mobile Legend, Free Fire dan beberapa game lainnya sehingga menyebabkan lupa dengan waktunya dan membiarkan waktunya begitu saja terbuang untuk hal yang kurang bermanfaat. ${ }^{16}$

Dalam konsep determinisme teknologi, dimana kemajuan teknologi sangat berpengaruh terhadap arah penemuan baru dan mempunyai peranan penting untuk membentuk perilaku masyarakat yang memungkinkan terjadinya perubahan dan juga revolusi sosial. $^{17}$

Dalam kehidupan sehari-hari handphone dirasa telah menjadi menjadi bagian yang penting dalam kehidupan bermasyarakat. Hal ini dapat dilihat dalam kehidupan sehari-hari misalnya ketika sedang bekerja bukannya fokus kepada pekerjaannya tetapi malah sibuk menjadi pelaku phubbing untuk mengecek notifikasi yang masuk handphonenya.

Merupakan suatu perubahan sosial yang sepertinya terlihat sepele, namun dampak yang terjadi begitu masif dan

\footnotetext{
16 Nurdianah Ulfa, Wawancara, Suryawangi (14 September 2021).

17 Teguh Ratmanto, "Determinisme Teknologi dalam Komunikasi dan Informasi”, Jurnal Komunikasi, Vol.6, No. 1 (Juni, 2005), hlm.. 44
} 
sungguh terlihat serta terasa, karena yang terjadi adalah perubahan pada pola pikir dan pola perilaku serta kebiasaan masyarakat. Azwar (2002) berpendapat bahwa seseorang akan dianggap berperilaku buruk atau menyimpang ketika perbuatan dan tingkah lakunya tidak sesuai dan melanggar norma yang ada. Pada kenyataannya sekarang ini, seseorang akan mudah melakukan pelanggaran terhadap norma yang ada. Bentuk-bentuk pelanggaran terhadap norma itulah wujud dari kemerosotan moral dan akhlak. ${ }^{18}$

Beberapa contoh yang lain seperti pada saat melakukan perkumpulan pada forum diskusi akan cenderung terlihat mengambil ponselnya dari saku atau tasnya, kemudian mencari materi atau isi bahasan yang akan didiskusikan, namun secara tidak langsung menjadikan lingkungan sekitar dan orang yang berada di dekatnya menjadi phubbeed atau korban dari perilaku phubbing itu sendiri yang akhirnya proses diskusi tidak akan berjalan dengan lancar dan efektif. ${ }^{19}$

Sungguh sangat disayangkan apabila terjadi perilaku yang demikian.

18 Lihat. Andri Kurniawan, "Analisis Peran Tradisi Nyaer Terhadap Dinamika Perilaku Sosial di Lombok", Tasamuh, Vol. 16. No. 2 (Juni, 2019), Hlm. 57.

${ }^{19}$ Nurdianah Ulfa, Wawancara, Suryawangi (14 September 2021).
Handphone pada mulannya tidak dibuat untuk mengubah perilaku atau aspek afektif masyarakat untuk berubah menuju ke arah yang negatif. Namun, jika salah dalam memanfaatkan atau tidak mempergunakannya sebagaimana mestinya, maka akan muncul kerugian didalamnya.

Sebagai suatu bentuk perwujudan dalam peran teori determinisme teknologi. Handphone sudah menjadi bentuk teknologi komunikasi yang mempunyai peranan penting alat komunikasi untuk dan membantu menghubungkan proses interaksi dari yang jauh menjadi dekat.

Secara umum, handphone sudah menjadi penting dalam kehidupan bermasyarakat khusunya pada masyarakat suryawangi, sehingga perlahan -lahan telah membentuk perubahan perilaku yang tidak disadari oleh penggunanya. Dampak yang ditimbulkan lebih kepada aspek afektf dan perilaku masyarakat. Perubahan sosial yang ditimbulkan akibat penggunaan Handphone yang secara berlebihan dan tidak terkontrol adalah Timbulnya Sikap Smombie ${ }^{20}$ dan Nomophobia ${ }^{21}$ bagi masyarakat.

\footnotetext{
${ }^{20}$ Istilah ini kependekan dari smartphone zombie, sebuah frase yang sebetulnya bisa membuat konotasi tidak sedap bagi pelakunya. Demi
} 
Komunikasi melalui handphone memerlukan etika yang baik sebagai pengatur jalannya proses komunikasi agar tetap mengedepankan sikap dan akhlak yang kepada lawan bicara sehingga tidak justru menyingkirkan komunikasi dalam ruang publik dan menjauhkan kepada hubungan interpersonal. $^{22}$

Menurut Foucalt yang dikutip Barker dipertegas oleh Hendrastomo moralitas terkait dengan sistem perintah dan larangan yang terbentuk dalam kaitannya dengan kode yang diformalkan. Etika terkait dengan praktik tentang bagaimana orang harus menghubungkan satu diri dengan diri yang lain dalam kehidupan seharihari. ${ }^{23}$ sehingga penggunaan handphone bagi masyarakat tetap berada dalam

mengidentifikasi perilaku, digunakan istilah tersebut. Smombie adalah orang yang terusmenerus menggunakan smartphone, handphone, atau gadget ketika sedang berjalan. Atau pejalan kaki yang memusatkan perhatian pada handphone tanpa memperhatikan lingkungan sekitar.

${ }^{21}$ Nomophobia merupakan kecemasan berlebihan akibat tidak membawa dan menggunakan handphone. Penyakit lain muncul akibat mata sering terpapar radiasi yang memancar dari cahaya pada layar gadget. Selain itu, radiasi dari energi elektrik pada organ tubuh tertentu.

22 Muliadi, Wawancara, Suryawangi (13 September 2021).

23 Abdul Sakban, "Perubahan Sosial Terhadap Pengguna Handphone Di Kalangan Remaja Kota Mataram", Civicus, Vol. 4, No, 2, (September, 2016), hlm. 73. ranah dan belenggu aturan etika berkomunikasi.

\section{E. KESIMPULAN}

Berdasarkan hasil penelitian dapat disimpulkan bahwa perilaku phubbing dapat merubah perilaku komunikasi pada masyarakat Suryawangi, terlebih pada era digital saat ini, dengan adanya teknologi komunikasi seperti handphone dapat mempermudah komunikasi dengan orang yang jauh. Dalam perkembangannya bukan hanya memberikan dampak positif bagi penggunanya,penggunaan handphone juga dapat memberikan dampak negatif apabila terlalu berlebihan dalam penggunaannya.

Penggunaan handphone sangat efektif terjadi terhadap perilaku phubbing berdasarkan pada penggunaannya. Sehingga berdampak terhadap berperilaku phubbing, baik itu dari segi kesadaran, rasa ketertarikan dan sikap yang tidak ingin jauh dengan dunia maya, seakan-akan dunia maya menjadi dunianya sendiri.

Masyarakat sudah terhipnotis dengan handphone selain dengan harganya yang terjangkau juga memberikan fitur-fitur menarik yang 
akan membuat para penggunanya selalu ingin menggenggamnya sehingga apapun yang ada dalam dunia sosial tidaklah menarik dibandingkan dengan yang diberikan oleh dunia maya melalui alat komunikasi tersebut. Perubahan komunikasi dipengaruhi oleh perkembangan teknologi sehingga melahirkan era baru dalam kehidupan bermasyarakat.

Gaya hidup di era digital merupakan sebuah fenomena bagi masyarakat saat ini. Hal ini menjelaskan bahwa gaya hidup digital merupakan revolusi gaya hidup. akibat perkembangan teknologi informasi dan komunikasi yang semakin pesat. Dengan menggunakan peralatan digital seperti handphone dapat mempermudah melakukan pekerjaan dengan lebih efisien dalam arti menghemat biaya dan juga waktu, dapat lebih efektif karena tujuan pekerjaan bisa dicapai lebih cepat dari sebelumnya.

Tergambar jelas bahwa tradisi penggunaan handphone secara berlebihan (phubbing) memberikan perubahan terhadap arah komunikasi masyarakat. Dimana pada era ini masyarakat disuguhkan cara berkomunikasi yang instan tanpa harus bertemu dan bertatap muka secara langsung dengan lawan bicara. Dunia maya sering kali digunakan untuk membangun citra diri bagi masyarakat digital, bagaimana mereka ingin dipandang oleh orang lain. Pergeseran besar terjadi ketika dunia digital mulai beradaptasi dengan kebutuhan masyarakat.

Sebagai masyarakat yang berada pada era digital seharusnya lebih memperkuat diri dengan Literasi digital, agar mampu menggunakan teknologi komunikasi dengan baik dan efektif, sehingga lebih mendapatkan dampak positif dari pada nampak negatif.

\section{F. DAFTAR PUSTAKA}

Aditia, Rafinitia. "Fenomena Phubbing:

Suatu Degradasi Relasi Sosial Sebagai Dampak Media Sosial", Jurnal Sosial dan Humaniora, Vol.2, No.8-14, April, 2021.

Chotpitayasunondh, Varoth, Karen M. Douglas. "The Effect of Phubbing On Social Interaction", Wiley: Journal Applied for Social Psychology, Vol.1, No.33, 2017.

Ekapravita, Raden Gita dan Iqbal Prabawa Wiguna. "Dampak Phubbing Pada Interaksi Sosial", e-Proceeding of Art \& Design, Vol. 6, No.3, Desember 2019.

Hamzani Khairul Ihsan, dkk 145 
Kurnia Shirley, dkk., "Kontrol Diri dan

Perilaku Phubbing pada remaja dijakarta", Media Ilmiah Psikologi, Vol.18. 2020.

Kurniawan, Andri. 2019. “Analisis Peran

Tradisi Nyaer Terhadap Dinamika Perilaku Sosial di Lombok". Tasâmuh 16(2),45-69.

Https://doi.org/10.20414/tasamuh. v16i2.865.

Muliadi. Wawancara, Suryawangi, 14 September 2021.

Racmi, Ivany. Hubungan Kesantunan Pergaulan dan perilaku phubbing pada mahasiswa UIR, Skripsi, Universitas Islam Riau, Pekanbaru, 2019.

Rafiq, Moh. "Defedency Theory(Melvin L. DeFleur dan Sandra Baall Rokeach)", Jurnal Hikmah Vol. VI, No.1, 2012.
Ratmanto, Teguh. "Determinisme Teknologi dala Komunikasi dan Informasi”, Jurnal Ilmu Komumikasi, Vol.6, No.1, Juni 2005.

Ridho, Muhammad Ali. Interaksi Sosial Pelaku Phubbing, Skripsi, UIN Sunan Ampel, Surabaya, 2019

Rosalinda Palit, dkk. "Perilaku Masyarakat Digital", Jurnal Administrasi Publik, Manado, Vol.1, No.99, Agustus 2021.

Sakban, Abdul. "Perubahan Sosial terhadap Pengguna Handphone di Kalangan Remaja Kota Mataram”, Jurnal CIVICUS, Vol.4, No.2, September 2006.

Ulfah, Nurdiana. Wawancara, Suryawangi, 14 September 2021 